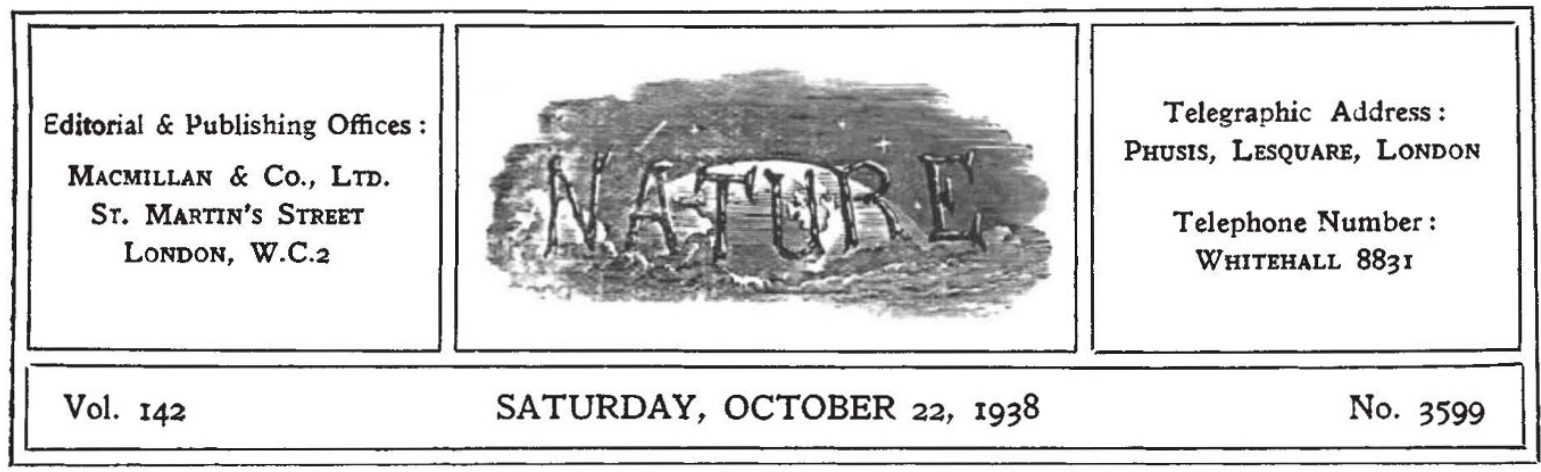

\title{
Concepts of Human Progress
}

\begin{abstract}
A FORTNIGHT ago, in an article entitled A "The Promotion of Peace", we referred to events which claimed the interest of the whole civilized world, and upon the settlement of which depended the lives of millions of people. We were able to record that, as the result of consultations between statesmen, an agreement was reached which, though its justice may be disputed, prevented nations from being thrust wantonly over the precipice into a world-war. Thanks to the facilities of rapid transit and world-wide direct communication, which science has placed at the service of statesman and press, the full weight of the world's judgment was brought to bear as the hour of crisis drew near, until perhaps-who can say?--it turned the scale. Had such rapid and extensive means of making plain the judgment and trend of opinion among peoples been available in 1914, actions which resulted in the Great War might have been averted.
\end{abstract}

In the first flush of enthusiasm at the recent preservation of peace, it seemed that the crisis through which we had passed had quickened perception of values in the essentials of life, to most of which we had been prepared to bid a long, and perhaps an eternal, farewell. Hope, founded on the promise of the Anglo-German pact, looked forward to the removal of the menace of war to set mankind free for the pursuit without distraction not merely of enjoyment of the advantages which the advancement of scientific knowledge holds out for the future, greater even than the wonders with which it has endowed mankind in the past generation, but also of real and substantial progress, in a healthier atmosphere, in the scientific study and resolution of the problems which lie at the root of world economic and social unrest.
Disillusion has been rapid, complete and painful. The first task to which we are now bidden to turn of necessity and at redoubled speed is armament and provision for defence. So much the more then are energies and resources withdrawn from the advancement of what we had come to realize were the essential needs of future development in human life. The sole palliation is that our aim is the preservation of the freedom of the spirit which alone consorts with the dignity of man.

Let there be no illusions as to the character of the struggle which will be involved in modern warfare. It is a reversion to the methods of savagery. In the scale of development of human society, war has played a useful and, biologically speaking, a necessary part. The society which at a certain stage of development depends upon the prowess of heroes pitted against their like, breeds heroes to ensure qualities essential to its survival in the struggle for existence. But the day of heroes in war is past. Modern war, which will be waged from the air, is the warfare of the primitive headhunter, in which the raider returns triumphant from his raid after the slaughter indiscriminately of man, woman or child. The principles of warfare are unchanged-"Find the forces of the enemy and destroy them" ; but those forces are no longer armed forces; they are the whole people, whose morale must be destroyed. Could any parallel be closer to the head-hunter, who brings back with each head something of the spiritual force of the enemy he has slain?

In the development-evolution in the popular sense-of progressive human societies, the line of advance has been towards ever-increasing aggregations of individuals-from family to tribe and from tribe, through a regular gradation of political 
units, to empire. If the warlike qualities have played their part in each of these forms of human association in securing that independence of existence which is essential for internal development, there has been an equal and parallel development of those qualities in the individual, which make for just and harmonious association between the members of a social group-the qualities of justice, of capacity for co-operation, of consideration for others, and care for the weak. It is these qualities which give solidarity to the group, and are no less conducive to its survival, than the warlike qualities which preserve it from aggression from outside.

Such social characters are, however, not only the essentials of internal peace and advancement, but also they react on those higher qualities of the human mind, in the exercise of which man approaches most nearly to exhibition of his specifically human characters, unaffected by cultural divergence. These higher manifestations of his spirit, if in origin based upon a tradition peculiar to his group, nevertheless in their highest development transcend such limitations. Of such are literature, art and scientific knowledge, which when they attain their highest powers, speak a universal language.

At the same time, with each advance in social gradation the system of social and religious ethics is extended to embrace a wider circle, until in certain of their concepts they, too, approach a universal appeal to mankind at large, rather than a restricted cultural group. No one has ever questioned that in these higher manifestations of the spirit, man attains, and will attain, his highest development, whatever may be his advancement in the field of the material. Further, it is a matter of experience, no less than a postulate of reason, that for their full and complete expansion and growth, free intercourse and exchange of experience and thought are essential, without barriers of race or political frontier to exclude any form of intellectual development as alien. While similarly the ethical system, in the long run, whether it be bound to a specific form of religious belief or not, will come to recognize the claims of ethical concepts ccmmon to humanity at large, irrespective of creed.

In the intercourse between national groups, which is become an essential condition of the develor ment of the activities of the higher faculties, civilized man has transcended the group to embrace humanity as a whole. As men bend their minds to the problems which arise in this extended outlook, if advancement is to continue it will demand more and more a scientific approach to these problems, which, however much they may depend upon conditions within the group, are world-wide in application or in effect.

In an increasing degree these problems will arise in connexion with the backward, no less than with advanced, peoples. An ever-growing sense of the responsibility of Western civilization to protect 'primitive' races from the more harmful and disintegrating effects of its own impact on their culture and institutions will, by the logic of circumstances, carry conviction that both wisdom and justice demand that this state of tutelage, no longer susceptible of exploitation for national advantage or prestige, should carry with it an obligation to develop in these peoples not only the capacity to deal with the special problems of their own government, but also to co-operate with the white man in the solution of questions of wider import. Events of the last decade, more especially in the economic field, have driven home forcibly the lesson that there are few peoples so remote, so self-sufficient-in short, so primitive-as to escape the repercussions of the major crises at the heart of civilization. Pursuit of the material benefits conferred in the spread of Western civilization has led to the assumption all too readily that ultimately Western ways of thought, Western beliefs will set the world standard. In the reaction which is at hand-nay, which has already begun in Africa and in the East-understanding, tolerance, and breadth of view can alone bring about the adjustment which will avert conflict.

Unfortunately, man's political and economic advancement has lagged behind his intellectual and material progress. The League of Nations, which represented an attempt to attain an aggregation transcending the national group, has accomplished much valuable work in the study of problems in which scientific and intellectual co-operation was possible without regard to national grouping. Nevertheless, it has failed in its main object, because in the international sphere its approach to political problems has been upon a national rather than an international basis. If the AngloGerman pact were, in fact, the first step towards a policy of discussion and conciliation, in which discussion proceeded to each specific problem with a scientific outlook and the aim of human, and not national, advancement and, be it added, without the accompaniment of the rattle of arms, we might indeed look for the approach of an era, of which the League of Nations was but the false dawn. 